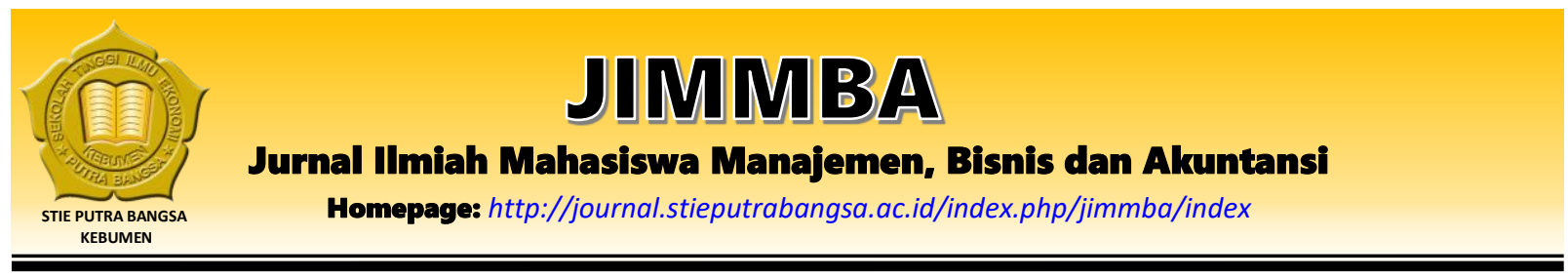

\title{
Analisis Prediksi Kebangkrutan dengan Model Altman, Springate, Ohlson dan Zmijewski Pada Perusahaan Food and Beverage di Bursa Efek Indonesia (BEI)
}

\author{
Munjiyah', Dwi Artati2 \\ 1,2Sekolah Tinggi Ilmu Ekonomi Putra Bangsa \\ Email: munjiyah317@gmail.com¹,dwiartati81@yahoo.co.id ${ }^{2}$
}

\section{ARTICLE INFO}

Article History:

Received: October $23^{\text {rd }} 2020$

Accepted: November $1^{\text {st }} 2020$

Published: December 31 2020

Keywords:

Bancrupty, Altman,

Springate, Ohlson,

Zmijewski

\begin{abstract}
The purpose of this study was to determine and analyze the prediction of bancrupty are most appropriate for use in its application to the food and beverage company listed on the Indonesia Stock Exchange (BEI) period 2015-2018. The study compared four models of prediction of bancrupty, the Altman, Springate, Ohlson and Zmijewski. Comparisons were made by analyzing the accuracy of each models. Data used in the form of annual financial statements published by the company on the website www.idx.com. The sampling technique is purposive sampling with total sample acquired nine companies. The results of one way ANOVA test is significant as 0,000. So, there are the difference results of bancrupty prediction of food and beverage company using Altman, Springate, Ohlson and Zmijewski. The survey result revealed that the model Ohlson is a prediction models with the highest level of accuracy of $100 \%$, with the type of error at $0 \%$. The model of Zmijewski has an accuracy rate of 92,31\% with the type error by $7,69 \%$. While the model of Altman has an accuracy rate of $69,23 \%$, with the type of error by $23,08 \%$ and the model of Springate has an accuracy rate of $69,23 \%$, with the type error at $30,77 \%$. Thus the accurate prediction models for food and beverage company registered in BEI is the Ohlson model, because have the best accuracy rate compared Altman, Springate and Zmijewski models.
\end{abstract}

\section{Pendahuluan}

Perusahaan food and beverage memiliki peranan penting dalam pertumbuhan ekonomi di Indonesia. Hal ini dibuktikan dengan meningkatnya kontribusi perusahaan food and beverage dalam investasi. Berdasarkan Laporan Kinerja Kementrian Perindustrian, investasi perusahaan food and beverage memiliki tren peningkatan yang cukup signifikan, bahkan pada tahun 2018 industri makanan merupakan sub sektor yang memiliki nilai investasi tertinggi yang mencapai Rp 39,08 triliun dengan jumlah proyek sebanyak 1.562 proyek. Berikut grafik yang menunjukkan jumlah investasi industri makanan berdasarkan Laporan Kinerja Kementrian Perindustrian tahun 2018. 


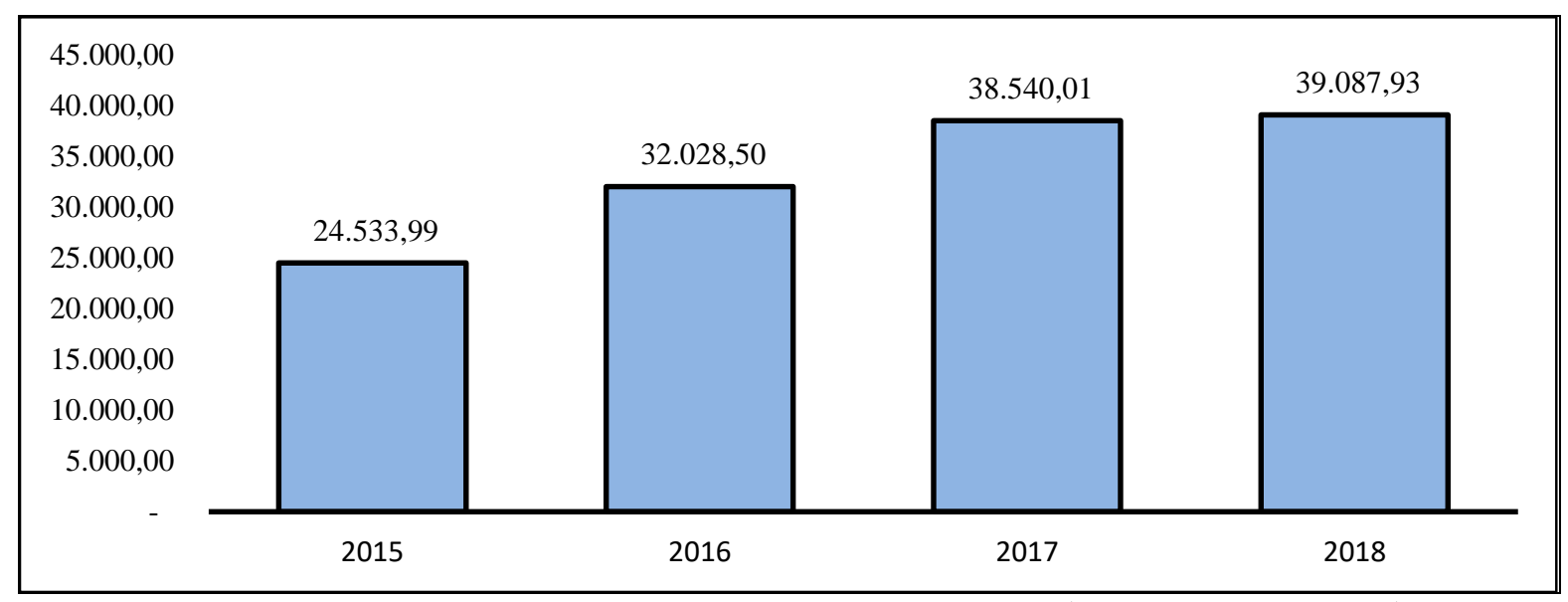

Gambar 1. Grafik Tingkat Investasi Industri Makanan (dalam triliun rupiah)

Sumber: BKPM diolah kemenperin

Pertumbuhan investasi yang terjadi pada perusahaan food and beverage tidak selamanya diikuti dengan berkembangnya semua industri yang berada pada sektor tersebut. Terdapat beberapa perusahaan food and beverage yang mengalami laba negatif selama tahun 2015 sampai tahun 2018. Berikut tabel yang menunjukkan laba negatif dari perusahan-perusahaan tersebut.

Tabel 1. Perusahaan Food and Beverage yang laba negatif (dalam jutaan rupiah)

\begin{tabular}{lcccc}
\hline Kode & \multicolumn{4}{c}{ Tahun } \\
\cline { 2 - 5 } Saham & $\mathbf{2 0 1 5}$ & $\mathbf{2 0 1 6}$ & $\mathbf{2 0 1 7}$ & $\mathbf{2 0 1 8}$ \\
\hline AISA & 500.435 & 898.431 & -846.809 & -123.513 \\
ALTO & -24.000 & -26.500 & -62.840 & -33.020 \\
PSDN & -42.620 & -36.662 & 32.151 & -46.599 \\
\hline
\end{tabular}

Sumber: data sekunder diolah, 2020

Melemahnya kondisi keuangan ditandai dengan kerugian yang dialami perusahaan selama beberapa tahun. Jika kerugian tidak dapat ditangani, maka perusahaan dikatakan gagal atau bangkrut. Menurut Peter dan Yoseph (2011:3) kebangkrutan (distressed) terdiri atas kegagalan ekonomi (economy distressed) dan kegagalan keuangan (financial distressed). Perusahaan dinyatakan mengalami kegagalan ekonomi (economy distressed) apabila pendapatan perusahaan hilang karena tidak mampu menutupi biayanya sendiri. Sedangkan perusahaan yang dinyatakan mengalami kegagalan keuangan (financial distressed) apabila perusahaan mempunyai kesulitan dana, baik dana dalam pengertian kas atau dalam pengertian modal kerja.

Perusahaan yang tidak mampu bersaing dengan perusahaan lainnya maka akan berakibat terhadap penurunan kinerja perusahaan yang dapat menimbulkan kebangkrutan (financial distress) atau kesulitan keuangan dan apabila tidak segera ditangani maka perusahaan akan mengalami kebangkrutan permanen. Terdapat beberapa metode untuk memprediksi kebangkrutan perusahaan antara lain metode Altman, Springate, Ohlson, dan Zmijewski. Altman (1968) mengadakan penelitian untuk menemukan model prediksi kebangkrutan yaitu analisis Multiple Diskriminant Analysis (MDA). Analisis ini mengkombinasikan beberapa rasio keuangan menjadi satu model sebagai pengukur tingkat kesehatan perusahaan yang terdiri lima rasio yang kemudian disebut dengan Z-score. Springate (1978) juga menggunakan metode statistik dan teknik pengambilan sampel yang sama dengan Altman tetapi sampelnya berbeda. Ohlson (1980) mengemukakan formula dan teknik pemilihan sampel yang berbeda 
dengan Altman (1968). Sampel dipilih dengan random sampling dengan menggunakan metodologi multinomial logit. Zmijewski (1983) menggunakan teori yang berbeda, yaitu bahwa profitabilitas, volatilitas, dan kondisi leverage perusahaan sebagai variabel terpenting dalam memprediksi kebangkrutan.

\section{Kajian Teori dan Telaah Literatur}

\section{Agency Theory}

Jensen dan Meckling (1976) menjelaskan agency theory sebagai suatu bentuk hubungan keagenan (agency relationship) yang timbul karena adanya kontrak yang ditetapkan antara principal yang menggunakan agent untuk melaksanakan jasa yang menjadi kepentingan principal dalam hal pemisahan kepemilikan dan kontrol perusahaan. Hubungan ini terkadang menimbulkan konflik kepentingan antara principal dan agent karena mungkin agent tidak selalu berbuat sesuai dengan kepetingan principal, sehingga memicu biaya keagenan (agency cost). Tujuan dari sistem pemisahan ini adalah untuk menciptakan efisiensi dan efektivitas dengan mempekerjakan agen-agen professional dalam mengelola perusahaan.

\section{Signaling Theory}

Teori sinyal (signaling theory) menurut Besley dan Brigham (2008:517) merupakan sebuah tindakan yang diambil oleh manajemen perusahaan yang memberikan petunjuk kepada investor tentang bagaimana manajemen memandang prospek perusahaan. Prinsip signaling theory yang dikemukakan oleh Atmaja (2008:6) yakni 'action convey information' yang menggambarkan bahwa setiap tindakan mengandung informasi. Signaling theory merupakan suatu pengumuman yang dianggap positif, jika manajer perusahaan menyampaikan perspektif masa depan perusahaan ke publik. Masa depan perusahaan dapat dilihat dari kondisi keuangan perusahaan.

\section{Kesulitan Keuangan dan Kebangkrutan}

Kesulitan keuangan merupakan salah satu kendala terbesar yang perlu diwaspadai oleh manajemen perusahaan. Kesulitan keuangan merupakan suatu situasi dimana arus kas operasi perusahaan tidak memadai untuk melunasi kewajiban-kewajiban lancar dan perusahaan terpaksa melakukan tindakan perbaikan dengan perubahan ukuran dan operasi perusahaan (Hapsari, 2012:103). Kesulitan keuangan digambarkan oleh Hanafi (2009:362) berada di antara dua titik ekstrem yaitu kesulitan likuiditas jangka pendek sampai titik insolvable. Kesulitan keuangan jangka pendek bersifat sementara. Jika kesulitan tersebut tidak ditangani, maka kesulitan keuangan akan berkembang menjadi kesulitan tidak solvable. Perusahaan dikatakan tidak solvable apabila hutang perusahaan lebih besar daripada asset yang dimiliki perusahaan.

Kebangkrutan adalah suatu kondisi disaat perusahaan mengalami ketidakcukupan dana untuk menjalankan usahanya. Menurut Peter dan Yoseph (2012:3) kebangkrutan dalam perusahaan dapat didefinisikan dalam dua pengertian, yaitu: kegagalan ekonomi (economic distressed) dimana kondisi perusahaan kehilangan pendapatan yang akibatnya tidak mampu menutupi biayanya sendiri. Kegagal keuangan (financial distressed) yang berarti perusahaan mempunyai kesulitan dana baik kas maupun modal kerja. 


\section{Model Prediksi Kebangkrutan}

\section{Model Altman}

Model Z-Score dikembangkan oleh Altman pada tahun 1968. Tahun 1995 Altman memodifikasi modelnya supaya dapat diterapkan pada semua perusahaan, seperti manufaktur, non manufaktur, dan penerbit obligasi di negara berkembang. Formula dari model Altman modifikasi yakni:

$Z=6,5 X 1+3,26 X 2+6,72 X 3+1,05 X 4$

Sumber: Ramadhani dan Niki, 2009

Keterangan:

$\mathrm{X} 1$ : working capital/ total asset

$\mathrm{X} 2$ : retained earnings/ total asset

$\mathrm{X} 3$ : earnings before interest and taxes/ total asset

X 4 : market value of equity/book value of debt

Klasifikasi perusahaan yang sehat dan bangkrut didasarkan pada nilai Z-Score model Altman modifikasi yaitu: jika $Z<1,1$ maka termasuk perusahaan bangkrut. Apabila $1,1<$ $Z<2,6$ termasuk perusahaan dalam kondisi grey area. Sedangkan jika $Z>2,6$ maka termasuk perusahaan sehat.

\section{Model Springate}

Model ini dikembangkan oleh Gorgon L.V. Springate pada tahun 1978 dengan menggunakan 40 perusahaan sebagai sampelnya. Model Springate dihitung sebagia berikut (Wulandari,et.al, 2014):

$S=1,03 X 1+3,07 X 2+0,66 X 3+0,4 X 4$

Keterangan:

$\mathrm{X} 1$ : working capital/ total asset

X2: net profit before interest and taxes/ total asset

$\mathrm{X} 3$ : net profit before taxes / current liabilities

$\mathrm{X} 4$ : sales/ total asset

Springate mengemukakan nilai cut off yang berlaku untuk model ini adalah 0,862 . Nilai Z yang lebih kecil dari 0,862 menunjukkan bahwa perusahaan tersebut diprediksi akan mengalami kebangkrutan.

\section{Model Ohlson}

Ohlson yang terinspirasi oleh penelitian-penelitian sebelumnya melakukan studi mengenai kebangkrutan dengan melakukan beberapa modifikasi pada tahun 1980. Ohlson menggunakan sampel sebanyak 105 perusahaan manufaktur yang bangkrut serta 2.058 perusahaan yang tidak bangkrut selama periode tersebut. Model tersebut adalah (Wulandari, 2014):

$\mathrm{O}=-1,32-0,407 \mathrm{X} 1+6,03 \mathrm{X} 2-1,43 \mathrm{X} 3+0,0757 \mathrm{X} 4-2,37 \mathrm{X} 5-1,83 \mathrm{X} 6+0,285 \mathrm{X} 7-1,72 \mathrm{X} 8-$ $0,521 \times 9$

Keterangan:

X1: $\log$ (total assets/ GNP price-level index) 
X2: total liabilities/ total assets

$\mathrm{X} 3$ : working capital/ total assets

X 4 : current liabilities/current assets

X5: 1 jika total liabilities $>$ total assets; 0 jika sebaliknya

$\mathrm{X} 6$ : net income/ total assets

X7: cash flow from operations/total liabilities

X8: 1 jika net income negatif; 0 jika sebaliknya

X9: (Nit - Nit-1) / (Nit + Nit-1)

Model ini memiliki cut off point optimal pada nilai 0,38. Maksud dari cut off ini adalah bahwa perusahaan yang memiliki nila $\mathrm{O}$ di atas 0,38 berarti perusahaan tersebut diprediksi distress. Sebaliknya, jika nilai O perusahaan di bawah 0,38 , maka perusahaan diprediksi tidak mengalami distress (Wulandari,et.al, 2014).

\section{Model Zmijewski}

Pada tahun 1984 Zmijewski mengkritik metode pengambilan sampel yang digunakan pendahulu-pendahulunya. Menurutnya matched-pair sampling memunculkan bias dalam hasil penelitian sebelumnya. Oleh karena itu, Zmijewski menggunakan teknik random sampling dalam penelitiannya, seperti dalam penelitian Ohlson. Dalam penelitiannya, Zmijewski mensyaratkan satu hal yang kursial. Proporsi dari sampel dan populasi harus ditentukan di awal, sehingga dapat besaran frekuensi kebangkrutan dengan membagi jumlah sampel yang mengalami kebangkrutan dengan jumlah sampel keseluruhan. Model yang dihasilkan Zmijewski adalah sebagai berikut (Peter dan Yoseph, 2011):

$X=-4,3-4,5 X 1+5,7 X 2-0,004 X 3$

Keterangan:

$X$ : bancrupty index

$\mathrm{X} 1$ : ROA (net income/ total assets)

$\mathrm{X} 2$ : Laverage (total debt/ total assets)

X3: Liquidity (current assets/ current liabilities)

Zmijewski menyatakan bahwa perusahaan dianggap distress jika probabilitasnya lebih besar dari 0 .

\section{Metode Penelitian}

Jenis penelitian ini kuantitatif deskriptif. Penelitian kuantitatif menurut Siregar (2013:8) adalah jenis penelitian yang datanya berupa angka. Sedangkan penelitian deskriptif merupakan penelitian yang dilakukan untuk mengetahui dan menjadi mampu untuk menjelaskan karakteristik variabel yang diteliti dalam suatu situasi (Syafitri dan Trisnadi, 2014:7). Objek dalam penelitian ini yaitu laporan keuangan tahunan perusahaan food and beverage. Metode pengumpulan data yang digunakan adalah metode dokumentasi (metode penelitian yang bersumber pada benda-benda tertulis (Setiawati, 2017:50) dengan menelusuri laporan tahunan perusahaan food and beverage yang terdaftar di Bursa Efek Indonesia (BEI).

Populasi dalam penelitian ini adalah perusahaan food and beverage yang terdaftar di Bursa Efek Indonesia (BEI) periode tahun 2015-2018. Jumlah populasi ada 17 perusahaan. Pengambilan sampel dalam penelitian ini menggunakan purposive sampling yang merupakan metode penetapan responden untuk dijadikan sampel berdasarkan pada kriteria-kriteria tertentu 
(Siregar, 2013:33). Sampel penelitian yang memenuhi kriteria berjumlah 13 perusahaan yakni ADES, AISA, ALTO, BUDI, CEKA, ICBP, INDF, MLBI, PSDN, ROTI, SKBM, STTP dan ULTJ.

Metode analisis data dilakukan dengan menghitung dengan model prediksi kebangkrutan Altman, Springate, Ohlson dan Zmijewski. Setelah hasil diperoleh kemudian dilakukan uji normalitas data untuk memperlihatkan bahwa sampel diambil dari populasi yang berdistribusi normal. Uji normalitas dilakukan dengan uji Kolmogorov-Smirnov untuk memperkuat normalitas data dengan melihat signifikansi. Jika signifikansi lebih besar dari 0,05 maka data dikatakan normal, sebaliknya jika signifikansi kurang dari 0,05 maka data tidak memenuhi asumsi normalitas. Uji hipotesis menggunakan uji beda One Way ANOVA dan menghitung tingkat akurasi model prediksi kebangkrutan dan type error nya dengan menggunakan rumus:

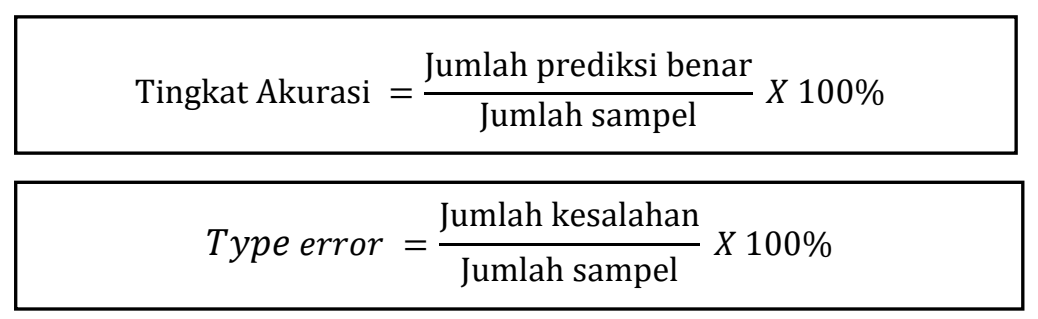

\section{Hasil dan Pembahasan}

Berdasarkan kriteria pengambilan sampel yang telah ditentukan maka terpilih 13 perusahaan food and beverage yang dapat dijadikan sampel penelitian dengan menggunakan acuan laporan keuangan empat tahun berturut-turut dari tahun 2015-2018. Masing-masing perusahaan dianalisis dengan menggunakan model prediksi kebangkrutan Altman, Springate, Ohlson dan Zmijewski.

Tabel 2. Hasil Perhitungan Model Prediksi Kebangkrutan

\begin{tabular}{ccccc}
\hline Kode & Altman & Springate & Ohlson & Zmijewski \\
\hline ADES & Sehat & Sehat & Sehat & Sehat \\
AISA & Bangkrut & Bangkrut & Sehat & Bangkrut \\
ALTO & Grey Area & Bangkrut & Sehat & Sehat \\
BUDI & Bangkrut & Bangkrut & Sehat & Sehat \\
CEKA & Sehat & Sehat & Sehat & Sehat \\
ICBP & Sehat & Sehat & Sehat & Sehat \\
INDF & Sehat & Sehat & Sehat & Sehat \\
MLBI & Sehat & Sehat & Sehat & Sehat \\
PSDN & Bangkrut & Bangkrut & Sehat & Sehat \\
ROTI & Sehat & Sehat & Sehat & Sehat \\
SKBM & Sehat & Sehat & Sehat & Sehat \\
STTP & Sehat & Sehat & Sehat & Sehat \\
ULTJ & Sehat & Sehat & Sehat & Sehat \\
\hline
\end{tabular}

Berdasarkan tabel hasil perhitungan prediksi kebangkrutan tersebut, model Altman memprediksi 3 perusahaan dalam kondisi bangkrut yaitu AISA, BUDI dan PSDN. Perusahaan dalam kondisi Grey Area ada 1 yaitu ALTO dan perusahaan lainnya dinyatakan dalam kondisi sehat. Model Springate memprediksi 4 perusahaan dalam kondisi bangkrut yaitu AISA, ALTO, BUDI dan PSDN, sedangkan yang lainnya dalam kondisi sehat. Model Ohlson memprediksi semua perusahaan dalam kondisi sehat dan model Zmijewski memprediksi 1 perusahaan bangkrut yaitu AISA dan lainnya dalam kondisi sehat. 
Model Zmijewski memprediksi 1 perusahaan yang mengalami kebangkrutan yaitu AISA. Hal ini terjadi karena adanya perbedaan kepentingan antara principal dan agent pada perusahaan tersebut. Sedangkan perusahaan food and beverage lainnya dapat mengatasi perbedaan tersebut dengan menggunakan biaya keagenan (agency cost).

Tabel 3. Uji Normalitas Kolmogorov-Smirnov

\begin{tabular}{llcrr}
\hline & Model Prediksi & Statistic & df & \multicolumn{2}{c}{ Sig. } \\
\hline \multirow{4}{*}{ Hasil Prediksi } & Altman & .222 & 13 & .079 \\
& Springate & .188 & 13 & .200 \\
& Ohlson & .116 & 13 & .200 \\
& Zmijewski & .212 & 13 & .114 \\
\hline
\end{tabular}

Sumber: data sekunder diolah, 2020

Berdasarkan tabel 3 diketahui nilai signifikansi masing-masing model $>0,05$ yang berarti bahwa data berdistribusi normal. Model Altman dengan signifikansi 0,079, model Springate dan Ohlson 0,200 serta model Zmijewski nilai signifikansinya sebesar 0,114.

Tabel 4. Uji One Way ANOVA

\begin{tabular}{lccccc}
\hline & Sum of Squares & $\mathrm{df}$ & Mean Square & F & Sig. \\
\hline Between Groups & $8.568 \mathrm{E}+10$ & 3 & $2.856 \mathrm{E}+10$ & 22.002 & .000 \\
Within Groups & $6.854+10$ & 48 & 1427825188 & & \\
Total & $1.542 \mathrm{E}+11$ & 51 & & & \\
\hline
\end{tabular}

Sumber: data sekunder diolah, 2020

Nilai F hitung pada tabel 4 sebesar 22.002 dengan signifikansi 0.000 . Signifikansi tersebut lebih kecil dari 0,05 sehingga H1 diterima. Artinya terdapat perbedaan hasil prediksi analisis kebangkrutan pada perusahaan food and beverage dengan menggunakan model Altman, Springate, Ohlson dan Zmijewski.

Tabel 5. Tingkat Akurasi Model Prediksi

\begin{tabular}{lcccc}
\hline Prediksi & Altman & Springate & Ohlson & Zmijewski \\
\hline Bangkrut & 3 & 4 & 0 & 1 \\
Grey Area & 1 & 0 & 0 & 0 \\
Sehat & 9 & 9 & 13 & 12 \\
Total & 13 & 13 & 13 & 13 \\
Akurasi & $69,23 \%$ & $69,23 \%$ & $100 \%$ & $92,31 \%$ \\
Type error I & $0 \%$ & $0 \%$ & $0 \%$ & $0 \%$ \\
Type error II & $23,08 \%$ & $30,77 \%$ & $0 \%$ & $7,69 \%$ \\
\hline
\end{tabular}

Sumber: data sekunder diolah, 2020

Tabel diatas menunjukkan akurasi model Altman sebesar 69,23\% dengan type error I sebesar $0 \%$ dan type error II sebesar 23,08\%. Sedangkan model Springate memiliki tingkat akurasi sebesar 69,23\% dengan type error I sebesar 0\% dan type error II sebesar 30,77\%. Model Ohlson memiliki tingkat akurasi $100 \%$ dengan type error I dan type error II sebesar $0 \%$. Model Zmijewski memiliki tingkat akurasi 92,31\% dengan type error I sebesar $0 \%$ dan type error II sebesar 7,69\%. 
Berdasarkan perhitungan akurasi yang telah dilakukan, model analisis yang paling efektif dan akurat dalam memprediksi kondisi keuangan pada perusahaan food and beverage periode 20152018 adalah metode Ohlson karena prediksi yang dihasilkan sesuai dengan kondisi yang sebenarnya yakni semua perusahaan dalm kondisi sehat. Hasil tersebut memberikan sinyal bagi pihak-pihak yang memiliki kepentingan terhadap perusahaan food and beverage. Signaling theory dianggap positif karena manajer perusahaan menyampaikan perspektif masa depan perusahaan ke publik.

\section{Penutup dan Saran}

\section{Simpulan}

Berdasarkan hasil penelitian dan pembahasan, maka dapat disimpulkan sebagai berikut:

1. Terdapat perbedaan hasil prediksi analisis kebangkrutan pada perusahaan food and beverage tahun 2015-2018 dengan menggunakan model Altman, Springate, Ohlson dan Zmijewski.

2. Terdapat satu model prediksi kebangkrutan pada perusahaan food and beverage tahun 20152018 dengan tingkat akurasi $100 \%$ yaitu model Ohlson dengan type error $0 \%$.

\section{Implikasi}

Hasil penelitian ini memberikan tambahan bukti empiris berkaitan dengan model prediksi kebangkrutan yang dapat digunakan oleh pihak-pihak yang perlu melakukan analisis kinerja perusahaan, dengan memilih model prediksi kebangkrutan yang memiliki hasil akurasi tertinggi.

\section{Implikasi Prakstis}

Berdasarkan hasil analisis yang telah dilakukan, maka implikasi praktis dari hasil penelitian antara lain:

1. Bagi manajer perusahaan yang akan menganalisis kesehatan perusahaan di masa mendatang, sebaiknya menggunakan model Ohlson yang memiliki tingkat akurasi tinggi yakni $100 \%$ sehingga risiko dalam memprediksi dapat diminimalisasi. Namun manajer juga perlu memperhatikan faktor lain di luar faktor keuangan yang mungkin menyebabkan penurunan kinerja perusahaan agar perusahaan dapat tetap mempertahankan usahanya.

2. Bagi investor yang akan melakukan investasi, sebaiknya tidak hanya memperhatikan harga saham, akan tetapi perhatikan juga kondisi keuangan perusahaan. Salah satu analisis yang dapat dilakukan investor yaitu dengan melakukan analisis prediksi kebangkrutan perusahaan untuk beberapa tahun mendatang, sehingga informasi tersebut dapat dijadikan salah satu tolak ukur investor untuk mengambil keputusan investasi.

\section{Implikasi Teoritis}

Hasil analisis yang telah dilakukan memiliki banyak kekurangan dan keterbatasan. Oleh karena itu, peneliti memberikan saran untuk penelitian selanjutnya, antara lain:

1. Menambah model prediksi yang digunakan menjadi lebih dari empat dan menggunakan model prediksi lainnya yang telah ditemukan oleh peneliti sebelumnya.

2. Penelitian berikutnya disarankan bukan lagi bersifat membandingkan model, namun bisa diarahkan untuk membuat model prediksi kebangkrutan baru yang dapat diaplikasikan di perusahaan-perusahaan yang ada di Indonesia. 


\section{Referensi}

Atmaja, L. S. (2008). Teori dan Praktik Manajemen Keuangan. Yogyakarta: ANDI.

Hanafi, M., \& Halim, A. (2009). Analisis Laporan Keuangan. Yogyakarta: UPP STIM YKPN.

Handoko, T. H. (2012). Manajemen Edisi 2. Yogyakarta: BPFE.

Husnan, S., \& Pudjiastuti, E. (2006). Dasar-dasar Manajemen Keuangan. Yogyakarta: UPP STIM YKPN.

Jensen, M. C., \& Meckling, W. H. (1976). Theory of the firm: Managerial behavior, agency costs and ownership structure. Journal of Financial Economics, 3(4), 305-360.

Laporan Kinerja Kementrian Perindustrian Tahun 2018. (2019). Biro Perencanaan Sekretariat Jenderal.

Munawir, S. (2014). Analisis Laporan Keuangan. Yogyakarta: Liberty.

Peter, P., \& Yoseph, Y. (2011). Analisis Kebangkrutan Dengan Metode Z-Score Altman, Springate Dan Zmijewski Pada PT. Indofood Sukses Makmur Tbk Periode 20052009. Maksi, 4(2).

Ramadhani, A. S., \& Lukviarman, N. (2009). Perbandingan analisis prediksi kebangkrutan menggunakan Model Altman pertama, Altman revisi, dan altman modifikasi dengan ukuran dan umur perusahaan sebagai variabel penjelas (studi pada perusahaan manufaktur yang terdaftar di Bursa Efek Indonesia). Jurnal Siasat Bisnis, 13(1), 15-28.

Setiawati, M. H. (2017). Analisis Metode Altman Z-Score, Springate dan Zmijewski Untuk Memprediksi Financial Distress Pada Perusahaan Food and Beverage Yang Terdaftar di Bursa Efek Indonesia (BEI) Periode 2011-2015. Skripsi Sarjana. (Tidak dipublikasikan), Bandar Lampung: Universitas Lampung.

Siregar, S. (2013). Metode Penelitian Kuantitatif Dilengkapi Dengan Perbandingan Perhitungan Manual \& SPSS. Jakarta: Penerbit Kencana.

Syafitri, L., \& Wijaya, T. (2014). Analisis Komparatif Dalam Memprediksi Kebangkrutan Pada PT Indofood Sukses Makmur Tbk. Jurusan Manajemen STIE MDP Palembang.

Wulandari, V. (2014). Analisis Perbandingan Model Altman, Springate, Ohlson, Fulmer, CAScore dan Zmijewski Dalam Memprediksi Financial Distress (studi empiris pada Perusahaan Food and Beverages yang Terdaftar di Bursa Efek Indonesia Periode 20102012). JOM FEKON, 1(2), 1-18. 